\title{
The relationship between health \& economic growth development in Pakistan
}

\author{
Zainab Qasim \\ University of Management and Technology Lahore (UMT) \\ Rida Fatima \\ University of Management and Technology Lahore (UMT)
}

\begin{abstract}
This paper investigates the connections between financial development and human improvement, recognizing two chains, one from monetary development to human advancement, the other from human advancement to monetary development. "Cross country backslides show an immense relationship in the two headings, with open utilizes on prosperity and preparing, strikingly female, especially noteworthy in the chain from economic growth to human development and the endeavor rate and pay scattering immense in the human development to economic growth chain." The essential inspiration driving this paper is to investigate the connection between human capital and monetary progress in Pakistan. "This discovering derives that, though both human headway and money related improvement should be commonly best in class, human improvement should be given progressive need." Result demonstrates that the two central divisions which need basic degree of thought are preparing and flourishing. This objective can be cleaned by overseeing abnormal territory of GDP to these parts.
\end{abstract}

Keywords: Economic Growth, GDP, Education, Health, Development.

\section{INTRODUCTION}

Pakistan positions 164th on the planet to the degree its excitement for getting ready and helpful organizations as estimation of its commitment to monetary progression, as shown by the essential ever reasonable examination arranging nations for their parts of human capital.

Human improvement has starting late been advanced as a conclusive objective of human development rather than money related improvement. Set out to create ability and limit improvement is fundamental for the headway strategy for a nation. "Cash related good conditions are comparatively higher in the event that we place resources into individuals and it effectly impacts the wages of the people."The most focal and basic factors being made on different, enhancements in the nature of the work power are an significant supporter of economic growth. However, while this two-route connection among human development and economic growth may presently be generally acknowledged, the specific factors connecting them have not been deliberately investigated. .In a nation's cash related progression, human capital expect a phenomenally central movement as it demonstrates the soundness of an economy and its family.

It is viewed as that capital and run of the mill assets are the moderate segments while human capital is a working variable of creation. Individuals can develop capital and make social and cash related affiliations. We can never make anything for cash related improvement, on the off chance that we can't build up the aptitudes of our kin. Obviously whether we have to use various resources reasonably, by then we have to develop the cutoff of our family through 
heading, limit advance and by quality improvement with the objective that we may trim down joblessness and update the course of action of headway. Human development will all around move in general economies, reliably from poor spots to continuously intemperate spots. Two or three cash related experts battle that this "cerebrum channel" makes poor spots less honored and rich spots continuously extra vagant. "Additionally, the manner by which development converts into salary dispersion and destitution decrease relies upon the idea of the development procedure specifically, the degree to which it depends on the age of work and on expanding rustic wages of enlargement in authentic hard and fast national yield, or veritable GDP (Gross Domestic Product) ."

Business is in a general sense the buy and opportunity of human capital: pros ensure their abilities, aptitudes, and time, and they pitch these focal points for relationship because of cash. "This is the thought crucial the reasoning that workers are truly instructors who pitch their time and predominance to customers, and that the estimation of one's work isn't ceaselessly settled on his or her extent of physical effort at any rate available estimation of his or her insight and limits."Two or three cash related pros fight that market rates are not utilizing any methods the primary concern that builds up the estimation of limits and information; particular affiliations, prominent instructing, and character can in like way influence the estimation of one's human capital.

\section{LITERATURE REVIEW}

In the midst of the earlier century, the reason for mix of analysts stayed on the effect of human capital dealing with structure on money related movement by building up the workplaces of arranging and achievement. " Different confirmable examinations have recorded a solid and positive in the meantime, accomplishments in human development themselves can make a basic commitment to monetary development. By utilizing the grown-up survival rate as a marker of well being status, Bhargava, et al. (2001) discovers positive connection between grown-up survival rate and monetary development. "Results remains relative when grown-up survival rate is superseded by future. For any situation, productivity rate have a negative relationship with money related improvement, Since life expectation is significantly influenced by the child mortality. " Development in workforce is generally lower than people improvement resultantly high wealth rate decline the financial advancement by putting extra weight on frenzy resources."

"The effect of instruction on the nature and development of fares, which, thus, influence the total development rate, is another manner by which human improvement impacts large scale execution." The instruction and abilities of a building up nation's work power impact the idea of its factor blessing and subsequently the piece of its exchange. " It has been contended that even 'incompetent' specialists in an advanced manufacturing plant regularly need the education, numeracy and control which are obtained in essential and lower optional school."

“ Hypothetical models consolidating aptitudes and learning as significant determinants of relative bit of leeway have prompted alterations of the straight forward two factor HeckscherOhlin model, clarifying the Leontief Paradox and the emotional achievement in the made fare development of a few creating nations, prominently those of East Asia."

“Examinations have appeared critical positive connection between's the development of made fares and the development of GDP,although genuine recognizable proof issues remain on the impact of preparing is more faulty than thriving." Past research studies have erroneously used dishonorable sections for estimation. For example if you are attempting to check human financing to the degree heading using school satisfaction, you are expecting that a period of 
school in one country is with respect to another which is insane. Later examinations have reviewed mental capacities to keep up a basic division from this bother. Interventions on improving human capital are other than difficult to survey on account of the time it takes to absolutely affect social markers and advancement. "Research shows that increments in bearing spending don't totally affect social pointers and headway for 10-15 years $(66 \%$ of the effect occurring inside 5 years), while the effects of growthes in prospering spending are brisk (Baldacci et al., 2008)."

Improved success and sustenance have been appeared to impact work profitability, particularly among progressively vile people. " A degree of work efficiency increments has been seen related with calorie increments, solidifying examinations of ranchers in Sierra Leone, sugar stick laborers in Guatemala, and street improvement specialists in Kenya." In these cases efficiency update seems to look for after reasonably quickly as present attestations of calories or downsized scale improvements are expanded. " In different cases the impacts are medium-run (as reflected in weight) or long-run (as reflected in stature), in light of proof from Bangladesh, Brazil, India, Sri Lanka, and the Philippines." A longitudinal examination of adolescents in Chile showed that giving nourishing enhancements to kids to avoid craving would make benefits six to different events the expense of the mediation as for extra profitability.

As far as advancement, the two nations are in a comparative circumstance. Despite the fact that India is showing improvement over Pakistan in certain zones, in others Pakistan leads the pack. Be that as it may, by and large, the circumstance doesn't look excessively great.Further more, the disparities in medicinal services are as yet striking. The report on tending to the disparity issue in "South Asia expressed that instruction and wellbeing imbalance in India is higher than in Pakistan. People in the rustic regions are at a higher danger of unhealthiness and demise during adolescence and have lower chances of accepting key medicinal services mediations." Also, rustic regions have lower middle medicinal services access than urban regions.

"Social insurance in Pakistan is a difficult issue, which should be tended to by the administration," he said.He explained by saying that there are wellbeing focuses in country zones where minor medical procedures occur and Prime Minister Nawaz Sharif has begun a program to build up the human services division alongside foundation and improving the offices in the sector.The requirement for training among the specialists is likewise dealt with as therapeutic universities have made motivators for understudies to participate and find out about legitimate strategies to manage patients in rustic and urban territories. Moreover, the understudy's taking on the projects are being acknowledged on legitimacy premise.

\section{Wellsprings of Data:}

\section{RESEARCH METHODOLOGY}

“ The National Health Vision endeavors to give a responsive bound together national bearing to stand up to different wellbeing challenges, while guaranteeing adherence to Universal Health Coverage as its definitive objective."

The guideline esteems include:
a) " Good administration"
b) “ Innovation and Transformation "
c) " Equity and master poor methodology"
d) “ Responsiveness ”
e) "Transparency and Accountability"
f) “ Integration and cross sectoral collaborations ” 
" The conveyance of value medicinal services administrations is a common obligation and the need activities exuding from this vision record would be working together with the commonplace needs, desires and needs. "The national wellbeing vision plans to resound with the goals and desires for areas. "The Federal government will bolster and encourage the regions in creating and executing their systems by giving the general vision and by encouraging/pushing for budgetary and specialized asset assembly to guarantee that fundamental wellbeing administrations are open to all natives."

\section{Destinations :}

" The National Health Vision has embraced the accompanying targets so as to improve the wellbeing and prosperity of the Pakistani society: "

a) Provide a brought together vision to improve Health while guaranteeing commonplace self-rule and assorted variety

b) Build lucidness to Federal and Provincial endeavors in merging the advancement, gaining from encounters and moving towards the all inclusive wellbeing inclusion.

c) Facilitate synchronization for shared characteristic crosswise over universal detailing and global bargains

d) Facilitate coordination for guideline, data accumulation, reconnaissance, and research for improved wellbeing frameworks

e) Provide a discovered national reason for graphing and executing SDGs, in organization with different divisions.

\section{Topical Pillars :}

National Health Vision manufactures its account on the accompanying topical columns. " These eight columns will clear a route for guaranteeing access, inclusion, quality and security, which are fundamental essentials for accomplishing a definitive objectives of wellbeing framework: improved wellbeing, responsiveness, social insurance, and productivity."

1“ Health Financing"

2" Health Service Delivery"

3 " Human Resource for Health"

4" Health Information Systems"

5 " Governance"

6 " Essential Medicines and Technology"

7 " Cross-sectoral linkages"

8“ Global Health Responsibilities"

"Each topical column or area is basically examined for the difficulties confronted, and a vital vision for which a general specialized help to the areas will be offered and facilitated by the Federal government."

\section{Wellbeing Financing :}

Difficulties:

"Government spending on wellbeing has dependably been not exactly ideal ( $0.6 \%$ of GDP). Most piece of the portions to wellbeing is devoured by the auxiliary and tertiary consideration, leaving only $15 \%$ for the preventive and essential medicinal services." There are wasteful aspects in the general wellbeing spending because of powerless administration frameworks, coming about in low use and inevitable slip by of assets. Installments are not connected to execution. Benefactor financing has been insignificant $(<2 \%$ of all out national wellbeing consumption). "The official contributor help (ODA) is far not as much as that submitted in the Paris revelation, and that also could be better adjusted and facilitated with governments' systems."Numerous populace sub-bunches need budgetary security, and face danger of 
calamitous wellbeing use.

\section{Vital Vision :}

" Government is aware that sufficient, responsive and effective wellbeing financing is the foundation of a nation's well-working wellbeing frameworks." The spending on wellbeing will be upheld as "venture" with the line services, account divisions and global advancement accomplices. " Bureaucratic and Provincial governments will expand designation to wellbeing as swore in Pakistan vision 2025 to 3\% of GDP, to amplify the compensation offs from putting resources into wellbeing."

Needs for wellbeing portions will be returned to, and a higher offer for basic wellbeing administration conveyance, preventive projects, correspondence, limit working of cutting edge wellbeing laborers, and administration will be guaranteed. "Professional poor social assurance activities (counting the ongoing national medical coverage plot) will keep on being financed and new activities (CCT, vouchers) will be propelled, encouraging access to basic essential, auxiliary wellbeing administrations and need diseases." There will be a dynamic development towards all inclusive wellbeing inclusion. RMNCAH and nourishment ventures will be expanded in a staged way. "Governments will create system to manufacture limit with respect to executing monetary control, return to equation for region assignments to look after equality, and concede money related self-rule to wellbeing foundations." Bureaucratic and common governments will create joint techniques expected to improve asset preparation for wellbeing from authority advancement help (ODA)/global advancement accomplices, private divisions' commitment, and through assessments, for example, sin charge.

\section{Advancement Growth Rate:}

Development models of neoclassical business analysts weight on venture and populace development in the relapse investigation. An expansion in speculation alongside a decrease in development rate of populace will advance monetary development. This hypothesis advances capital collection as the motor of monetary development. The venture development is constrained by the accessibility of assets what's more, it is in this feeling capital shortage assumes a significant job in the assurance of monetary development. It is accepted that the varieties in the accessible innovation smooth the advancement of development process. So the center ought to be to enable the contributions to request to stream into various areas of the economy. "Profit for capital decides speculations in this investigation we incorporate venture development rate (as level of GDP) in our examination."

\section{Checking and Evaluation:}

"A checking and assessment (M\&E) component will be created for the National Health Vision 2016-2025 it would be in the state of a M\&E Framework and Plan, connected and composed with the Planning Commission for SDG revealing, common and territory/district wellbeing divisions for arrangement with systems, and other partners. " The MONHSRC will organize for these capacities.

“The M\&E plan would portray in detail the particular jobs of various features of the wellbeing framework; the procedures of information procurement, stream, examination, use and criticism; asset necessities; institutional/hierarchical foundation needs (at various dimensions); investigation of at present accessible capabilities and limits and explicit pointers and their courses of events for checking execution and results." It will likewise characterize how various dimensions of government can use the information and data from such a framework and even recommend restorative activities where required. 
“The M\&E system and its operational arrangement will concentrate on advancement towards results and effect, by building up a proper parity of M\&E apparatuses and approaches significant to the proposed destinations, exercises, and targets." Checking information will be confirmed autonomously (by means of outsiders). A significant part of the checking will be executed by the common wellbeing frameworks fortifying units (or equal elements). Together these units will follow the advancement of the wellbeing of the country. " A national body (abnormal state Inter common wellbeing and populace chamber) will have the duty of oversight of the execution of the national wellbeing vision. It will support the reports for introduction to the parliament on yearly premise."

\section{Client Training:}

"We have just observed that the help group helped in distinguishing the necessities. The help group likewise helped in client preparing."The advancement group arranged preparing materials and prepared the help builds in the utilization of the new framework. "As the client preparing was fundamentally the utilization of a couple of structures appropriate to the specific capacity, it didn't present much issue to the help faculty in picking up capability in the framework and later exhibiting the equivalent to the end clients." The preparation was given in gatherings of clients managing the specific practical module. Other than the front-work area clients, who are in charge of the underlying enrollment of patients, different gatherings were agreeable in utilizing the framework following a sum of 6 hours preparing. The front work area gathering was given 10 hours of preparing. This could described to the way that clients previously had introduction to the restrictive framework for almost a year.

\section{CONCLUSION \& RECOMENDATION}

"As the investigation and models in this report have illustrated, a wide cluster of components impacts a network's wellbeing, and numerous substances in the network share duty regarding keeping up and improving its wellbeing." The potential after effects of test showed that there are for quite a while run association between money related movement, preparing enrollment, CPI swelling, background improvement, head count degree and fixed capital improvement. Arranging selection report (EEI) has tremendous and positive effect on money related progress which is as shown by the theory. It deduces increase in preparing assurance revives money related progress. "Adding to the enthusiasm for wellbeing improvement and execution observing is a more extensive acknowledgment that wellbeing holds onto prosperity just as the nonattendance of ailment." " For the two individuals and peoples, prosperity can be accepted to rely upon therapeutic thought just as on various factors including solitary lead and genetic beauty care products and social and fiscal conditions."

\section{Reference:}

Abbas, Q. (2001). Endogenous Growth and Human Capital: A Comparative Study of Pakistan also, Sri Lanka .The Pakistan Development Review, 40(4), 987-1007.

Abbasa, Q. and Peck, J. M. (2007).Human Capital and Economic Growth: Pakistan 1960-2003. Abosetegn, M.( 2000). Employmrnt Market Information and Occupational Guidance for

Tertiary Level Students in Ethiopia: The Case of Prospective Agricultural College Graduates, School of Graduate Studies, Addis Ababa University, Addis Ababa.

Afzal, M., Farooq, M.S. ,Ahmad, H.K. and Begum, I.\& Quddus, M.A. (2010). Relationship Between School Education and Economic Growth in Pakistan. Pakistan Economic and Social Review, 48 (1),39-60.

Agiomirgianakis, G., Asterious, D. and Monastiriotis. V. (2002). Human Capital and Economic Development Revisited: A Dynamic Panel Data Study. Int'l Advances in Economics, 8(3), 177-187.

Akram, N. and Khan, M. (2008).The Long Term Impact of Health on Economic Growth in Pakistan. The Pakistan Development Review, 47(4),487-500. 
Amjad, R. (2005). Abilities and Competitiveness: Can Pakistan Break Out of the Low-level Skills Trap?. The Pakistan Development Review, 44(4), 387-409.

Akram, N. (2008). The long haul Impact of wellbeing on monetary development in Pakistan. The Pakistan Development Review, 47(4), 487-500.

Afzal, M. (2010). Connection between school training and monetary development in Pakistan: ARDL limits testing way to deal with cointegration. Pakistan Economic and Social Review, 48(1), 39-60.

Amjad, R. (2005). Aptitudes and intensity: Can Pakistan break out of the low-level abilities trap? The Pakistan Development Review, 44(4), 387-409.

Qadri, F. S., and Abdul Waheed, W. (2011). Human capital and financial development: Time arrangement proof from Pakistan. Pakistan Business Review, 1, 815-833

Mehrara, M., and Musai, M. (2013). The connection between financial development and human capital in creating nations. Worldwide Letters of Social and Humanistic Sciences, 5, 55-62.

Abbas, Q., and Foreman-Peck, J. S. (2008). Human capital and financial development: Pakistan 1960-2003. Lahore Journal of Economics, 13(1), 1-27.

Ali, S., Farooq, F., and Chaudhry, I. S. (2012). Human capital development and financial development in Pakistan. Pakistan Journal of Social Sciences, 32(1), 229-240.

Shehzad, S. (2004). In what manner Can Pakistan Reduce Infant and Child Mortality Rates? A Decomposition Analysis. Economical Development Policy Institute.

Ashton, D.N. and Sung, J.(2002).Supporting Workplace Learning for High Performance Working.

A Research Report for International Labor Organization, Geneva. Barkley, A. P.(1991).

The Determinants of Interdistrict Labor In-relocation in Pakistan, 1971- 1980. The Pakistan Development Review,30(3), 275-296.

Barro, R.J. and Martin, S.(1995). Monetary Growth, McGraw Hill, New York.

Becker , G. (1964). Human Capital, Columbia University Press.

Birdsall, N., Ross, D. and Sabot, R.(1993).Underinvestment in Education: How Much Growth Has Pakistan Forgone?. The Pakistan Development Review, 32 (4), 453-499.

Bjorkman, J.W. (1986). Wellbeing Policies and Human Capital. The Case of Pakistan . The Pakistan Improvement Review, 25 (3), 281-330.

Bils, M. and Peter, J.K. (2000). Does Schooling cause Growth?. American Economic Review, 90(5) , 1160-1183. 